\title{
Simulation and Evaluation of Dust Emission with Polair3D-SIREAM Model over West Africa Focused on Ouagadougou (Burkina Faso)
}

\author{
Bernard Nana $^{1,2}$, Oumar Sanogo ${ }^{3}$, Issoufou Ouarma' ${ }^{1}$, Antoine Béré1, Jean Koulidiati1 \\ ${ }^{1}$ Laboratoire de Physique et de Chimie de l'Environnement (LPCE), Université Ouaga I Professeur Joseph KI-ZERBO, \\ Ouagadougou, Burkina Faso \\ ${ }^{2}$ Institut des Sciences (IDS), Ouagadougou, Burkina Faso \\ ${ }^{3}$ Institut de Recherche en Sciences Appliquées et Technologies, Centre National de la Recherche Scientifique et Technologique, \\ Ouagadougou, Burkina Faso \\ Email: nsbernard@yahoo.fr
}

How to cite this paper: Nana, B., Sanogo, O., Ouarma, I., Béré, A. and Koulidiati, J. (2019) Simulation and Evaluation of Dust Emission with Polair3D-SIREAM Model over West Africa Focused on Ouagadougou (Burkina Faso). Journal of Environmental Protection, 10, 80-102.

https://doi.org/10.4236/jep.2019.101006

Received: December 1, 2018

Accepted: January 18, 2019

Published: January 21, 2019

Copyright (C 2019 by author(s) and Scientific Research Publishing Inc. This work is licensed under the Creative Commons Attribution International License (CC BY 4.0).

http://creativecommons.org/licenses/by/4.0/

\begin{abstract}
The study of air pollution is recent in West Africa. There is a lack of data on air pollution. However, some studies conducted in West Africa show that air quality is a concern. Population growth and massive vehicles imports are contributing to the deterioration of this air quality. In this work, we present the modelling of desert aerosols using a CTM Polair3D-SIREAM. The objective is to evaluate the ability of Polair3D-SIREAM to reproduce observations of $\mathrm{PM}_{10}$ and Aerosol Optical Thicknesses (AOT). A simulation with Polair3D-SIREAM was carried out in West Africa, focused on Ouagadougou (Burkina Faso) for 2007. The model of Marticorena and Bergametti (1995), MB95, was used to estimate desert aerosols emissions. The total emission of dust modelled is $52.2 \mathrm{Tg}$. For the evaluation of $\mathrm{PM}_{10}$, the simulated averages remained within the same orders of magnitude as the observed averages. Correlations are low in all the observation sites. The other indicators are similar to those found by Schmechtig et al. (2011). Performance criteria of Boylan and Russel (2006) are met for the observation sites of Ouagadougou and Ilorin (Nigeria). For the AOTs, the correlations are significantly improved, in particular, at the sites of Ouagadougou and Ilorin. Performance criteria of Boylan are met for all observation sites. However, the performance goals are only achieved for Ouagadougou and Ilorin.
\end{abstract}

\section{Keywords}

Air Pollution, Dust Emission Modelling, $\mathrm{PM}_{10}$, Aerosol Optical Thickness, Polair3D-SIREAM 


\section{Introduction}

The World Health Organization (WHO) estimates that in 2012, about 7 million people died prematurely due to air pollution. This estimation represents more than twice than many previous estimates and confirms that air pollution is now the main environmental health risk in the world [1]. In Africa, the problem of air pollution is recent, and there is a lack of data on pollutant emissions in cities. However, WHO also shows that more than $90 \%$ of air pollution-related deaths are in low-income countries such as sub-Saharan Africa. Studies previously conducted in West Africa showed that air quality is more and more deteriorating as a result of rapid population growth and the massive import of second-hand vehicles with an average age of 15 years; that is a source of major pollution [2] [3] [4].

Nana [5] and CREPA [6] showed that in the case of Burkina Faso, in particular the city of Ouagadougou, air pollution related to hydrocarbons and desert aerosols is a major concern. Desert aerosols contain more than $80 \%$ dust [7] [8]. These aerosols come from Sahara emissions and are transported to the Sahel area. Studies by Marticorena and Bergametti [9], Laurent et al. [10], Engelstaedter et al. [11], Miller et al. [12], Ginoux et al. [13], Formenti et al. [14] and Goudie [15] have shown that the Sahara is the largest source of dust emissions in the world. This dust, in addition to its impact on health, acts on the attenuation of solar radiation and therefore on the Earth's climate [16].

The total quantity of dust particles displaced by the wind, called horizontal flux (Q), depends mainly on wind velocity and the size distribution of soil particles. The intensity or dust flux, i.e. the vertical flux (F), also called the emission rate, is rather influenced by the soil's ability to release fine transportable particles [17] [18].

Several dust emission schemes exist to evaluate horizontal and vertical flux. All these schemes take into account three processes for dust emission, i.e. erosion threshold, saltation and sandblasting. The difference between these schemes lies in the parameterizations used to calculate each factor. A common physical basis for these schemes includes the idea that the vertical dust emission rate $F$ is proportional to the saltation flux $Q$. For the schemes proposed in Marticorena and Bergametti [9], Marticorena et al. [19], Alfaro et al. [20], Alfaro et al. [21], Alfaro and Gomes [22] and Gong et al. [23], this proportionality depends on the binding energy of the dust particle. For the emission scheme of Shao et al. [18] [24] [25], this proportionality depends on the plasticity pressure of the soil. In our study, the emission scheme developed by Marticorena and Bergametti [9] [19] (MB95 model, here after) was chosen to estimate dust emission because it is less sensitive to the particle size distribution on the ground. Indeed, the authors In and Park [26], Gong et al. [23] and Shao [25] show that the models developed by Alfaro and Gomes [22] and Shao [25] are very sensitive to input data on soil grain size distribution. Given that the size distribution of soil particles in arid regions is poorly known [27], the use of these models will generate uncertainties in 
the size and mass distribution. In addition, Zhao et al. [28] show that the scheme Marticorena and Bergametti [9], better reports surface concentrations in most deserts in East Asia compared to other schemes.

Several studies have been conducted to estimate dust emissions in the Sahara region above $15^{\circ}$ north latitude [10] [29] [30] [31] [32]. Schmechtig et al. [32] simulated desert dust transport using the chemistry-transport model (CTM), CHIMERE-DUST model [33] [34] in the area between the latitudes $15^{\circ} \mathrm{N}$ and $39^{\circ} \mathrm{N}$. Observation data from the African Monsoon Multidisciplinary Analysis (AMMA) project [35] stations were used for evaluation.

The final aim of our study is to focus on the city of Ouagadougou in Burkina Faso, located below $15^{\circ} \mathrm{N}$ latitude. In this article, we however consider simulation at the regional scale, over West Africa, centered on Burkina Faso, between the latitudes $4^{\circ} \mathrm{N}$ and $24^{\circ} \mathrm{N}$. The objective is to generate concentrations fields for the boundary and initial conditions of a smaller domain over Ouagadougou. It should also be noted that in our study area, there are no data on desert aerosol emissions. The data that exist come from global models [36] [37] that do not necessarily reflect the reality on the field. In our case, we use another CTM, Polair3D-SIREAM (which we will describe below) for the simulations.

This work is a contribution to the study of the impact of desert aerosol emissions on air quality modelling in West Africa. The Polair3D-SIREAM CTM from the Polyphemus system (http://cerea.enpc.fr/polyphemus/) was used to evaluate the dispersion of pollutants. The purpose of this study is to assess the ability of Polair3D-SIREAM to reproduce ground observations of $\mathrm{PM}_{10}$ and aerosols optical thicknesses (AOT). The model MB95 [9] was used to estimate the desert aerosol emissions in the study domain. Observational data of $\mathrm{PM}_{10}$ from the AMMA measurement campaign were used for evaluation of the concentrations simulated at ground level. Observational data of the AERONET (AErosol RObotic NETwork) were used for evaluation of the Aerosols Optical Thicknesses (AOT) simulated.

\section{Materials and Methods}

This section describes the emission model used to estimate the quantities of dust emitted in the study area. It also presents Polair3D-SIREAM and the input data.

\subsection{Dust Emission Model}

The emission of mineral dust by wind in arid regions is a process, which depends on the characteristics of the soil surface and meteorological conditions. The emission of a dust particle is a power function which depends on the wind friction velocity $U^{*}$, but which only occurs if a threshold value of the wind friction velocity $\left(U_{t}^{*}\right)$, is reached. This threshold of the wind friction velocity depends mainly on the size distribution of soil particles, roughness induced by the presence of non-erodible elements on the soil surface and soil moisture. Once the threshold of wind friction velocity is reached, the soil particles start moving 
in a horizontal direction, which is called saltation. It should be noted that the horizontal movement of particles depending on wind velocity and their sizes, is done not only by salting but also by creeping which consists of a rolling on the ground of large particles of diameter $\geq 1000 \mu \mathrm{m}$ [38]. However, "sandblasting" is the main process of dust production source: it consists of the release of fine dust particles by the impact of soil particles on the surface and/or into a disintegration of the aggregated particles on the ground. The grains of sand that are in saltation, provide the kinetic energy necessary to overcome the forces that retain dust particles on the ground.

\subsubsection{Horizontal Flux}

The horizontal dust flux $Q$ in $\left(\mathrm{g} \cdot \mathrm{cm}^{-1} \cdot \mathrm{s}^{-1}\right)$, defined as the mass of particles passing through a vertical surface per second perpendicular to the ground flux is calculated by Marticorena and Bergametti [9] from the Equation (1).

$$
Q=E \frac{\rho a}{g} U^{* 3} \sum_{D_{p}}\left(1+\frac{U_{t}^{*}\left(D_{p}, Z_{0}, z_{0 s}\right)}{U^{*}}\right)\left(1-\frac{U_{t}^{*}\left(D_{p}, Z_{0}, Z_{0 s}\right)^{2}}{U^{* 2}}\right) d S_{r e l}\left(D_{p}\right) d D_{p}(1)
$$

where $E$ is the fraction of the erodible surface (it corresponds to the part of the surface which is not protected against wind erosion by surface elements (rocks, trees, houses, etc.)), $d S_{\text {rel }}\left(D_{p}\right)$ is the area covered by the particles of diameter $D_{p}$, and $\int d S_{r e l}\left(D_{p}\right) d D_{p}=1$.

This Equation (1) is derived from the equation of White [39]. But, here Marticorena and Bergametti [9] makes a modification to take into account the threshold wind friction velocity, $U_{t}^{*}\left(D_{p}, Z_{0}, z_{0 s}\right)$ (in $\left.\mathrm{cm} \cdot \mathrm{s}^{-1}\right) . Z_{0}$, the roughness length, $z_{0 s}$, the smooth roughness length, $\rho a$, the air density.

To take into account the soil moisture $\mathrm{w}$, which increases $U_{t}^{*}$, we use a correction that is calculated according to Fécan et al. [40], as a function of residual moisture $w$.

\subsubsection{Vertical Flux (or Emission Rate)}

Vertical flux is defined as the mass of particles that pass through per unit of time a surface of unit width, parallel to the surface. Basing on Gillette's experimental results [17], Marticorena and Bergametti [9] have established an empirical relationship of proportionality of the vertical flux $F\left(\mathrm{~g} \cdot \mathrm{cm}^{-2} \cdot \mathrm{s}^{-1}\right)$ in relation with the horizontal flux $Q$, for clay contents between $0 \%$ and $20 \%$ :

$$
\alpha=\frac{F}{Q}=10^{(0.134(\% \text { clay })-6)}
$$

$\alpha$ is the efficiency coefficient of fine particle production by sandblasting (or sandblasting efficiency). The flux measured by Gillette [17] is a particle flux with a diameter less than $20 \mu \mathrm{m}$. It should be noted that one of the major limitations of this expression, in addition to its empirical character, it only provides the total mass emitted flux, without any information on the distribution of this flux in the different aerosol size classes. 


\subsubsection{Input Data of the MB95 Model}

The main input data of the model are the surface properties and meteorological data. For surface properties, these were determined from data calculated by Laurent et al. [10] in the Sahara desert and a part of Sahel.

Surface property data: the surface data are mainly the aerodynamic roughness length $\left(Z_{0}\right)$, smooth roughness $\left(Z_{0 s}\right)$, soil size distribution and texture, including the clay percentage. Marticorena et al. [41] and Laurent et al. [42] have established a mapping of aerodynamic roughness length for North Africa (latitude: $16^{\circ} \mathrm{N}$ to $39^{\circ} \mathrm{N}$, longitude: $19^{\circ} \mathrm{W}$ to $40^{\circ} \mathrm{E}$ ), at a spatial resolution of $0.25^{\circ} \times 0.25^{\circ}$. These roughness data were used for the present simulations. In this study, we used the soil parameters initially mapped by Marticorena et al. [19] and Callot et al. [43] at a resolution of $1^{\circ} \times 1^{\circ}$ for North Africa and adjusted by Laurent et al. [10] at a resolution of $0.25^{\circ} \times 0.25^{\circ}$ using the same geomorphological approach. The data of Laurent et al. [10] is used to establish texture, residual moisture and the coefficient $\alpha\left(\mathrm{cm}^{-1}\right)$ of the different types of soils found in the northern zone of Africa (latitude $>16^{\circ} \mathrm{N}$ ) were established following Laurent et al. [10]. We use the fraction of erodible surface $E$ calculated according to Laurent et al. [27] who estimated $E$ as a linear logarithmic function of $Z_{0}$ when $Z_{0}$ is greater than $3.10^{-3} \mathrm{~cm}$ (Equation (3)):

$$
\begin{aligned}
Z_{0} & <3.10^{-3} \mathrm{~cm} ; E=1 \\
Z_{0}>3.10^{-3} \mathrm{~cm} ; E & =0.7304-\left(0.0804 \times \log _{10}\left(Z_{0}\right)\right)
\end{aligned}
$$

Our study domain is West Africa, focused on Burkina Faso. It extends in latitude $\left(4^{\circ} \mathrm{N}-24^{\circ} \mathrm{N}\right)$ and longitude $\left(12^{\circ} \mathrm{W}-7.5^{\circ} \mathrm{E}\right)$ (Figure 1). Note that this area is not fully covered by the study of Laurent et al. [10]. For surface property data below latitude $16^{\circ} \mathrm{N}$, we assumed that there was nodust emission, so the surface properties are set to zero.

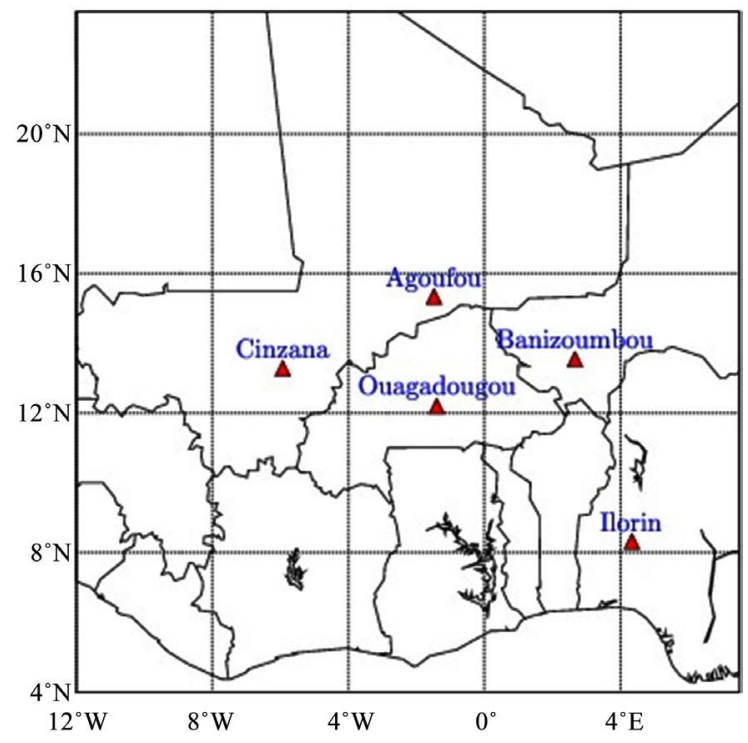

Figure 1. Study domain covering West Africa. Red triangles show the locations of observation stations. 
Meteorological data: the meteorological data used by the dust emission model are surface wind velocities and soil moisture. The meteorological data used in this work are provided by the database of the European Centre for Medium-Range Weather Forecasts (ECMWF).

These data are results of the ECMWF operational model, provided with a spatial resolution of $0.25^{\circ}(\Delta x=0.25 ; \Delta y=0.25)$. Approximate domain: [ $\left.-20 ; 3\right] \times$ [50; 80] $\left(x_{\min }=-20 ; N_{\mathrm{x}}=281 ; y_{\min }=3 ; N_{y}=309\right)$; vertical resolution: 54 hybrid levels (from 38 to 91 model levels) $\left(N_{z}=54\right)$.

\subsection{Polair3D-SIREAM Description and Input Data}

The study domain is the same as the one used to calculate dust emissions. We considered five (5) vertical levels over $3 \mathrm{~km}(0 ; 50 ; 600 ; 1200 ; 2000 ; 3000)$ for a horizontal resolution of $0.5^{\circ} \times 0.5^{\circ}$ (see Figure 1). The simulated year is chosen to be 2007 due to the availability of specific observation in Ouagadougou.

\subsubsection{Model Description}

In our simulations, we used the Eulerian CTM of the Polyphemus system [44] which is Polair3D, implemented with the SIREAM (Size Resolve Aerosol Model) aerosol module [45]. The Polair3D model solves the chemistry transport equation in an Eulerian framework. The numerical strategy implemented to solve advection by mean wind, the turbulent diffusion, scavenging by rain and dry deposition are described in [45]. The SIREAM module separates the particle size distribution into sections and solves the general dynamic equation by separating coagulation, condensation/evaporation and nucleation. SIREAM solves aerosols according to their size. It is coupled to the Hydrophilic/Hydrophobic Organic model $\left(\mathrm{H}^{2} \mathrm{O}\right)$ for the formation of Secondary Organic Aerosols (SOA) [46], ISORROPIA [47] for the thermodynamics of inorganic aerosols. The Carbon Bond mechanism (CB05) is used for chemical kinetics in the gas phase [48] [49] [50].

Dry deposition of gaseous species is described using the Zhang et al. [51] model with modifications proposed in Simpson et al. [52]. The dry deposition of aerosols is calculated according to Zhang et al. [53] parameterization. Dry deposition rates are calculated for 24 USGS soil types.

\subsubsection{Input Data}

Polair3D-SIREAM input data are essentially meteorological data, land use data, emissions data, boundary conditions and initial conditions.

The meteorological data are derived from the ECMWF numerical prediction model on a 54-level hybrid vertical coordinate, and a horizontal grid in latitude/longitude of $0.25^{\circ} \times 0.25^{\circ}$ resolution. They are available with a frequency of 3 hours.

Land cover data are from the USGS (The United States Geological Survey) database. 24 different soils types are defined. These types of soils are also used for the models of deposition and biogenic emissions. 
The anthropogenic emissions data for $\mathrm{CO}, \mathrm{NO}_{2}, \mathrm{SO}_{2}$ and NMVOCs are from the EDGAR (Emission Database for Global Atmospheric Research), the versions used are EDGAR-v3.2 and EDGAR-v4 [36] [37] [54]. These data are available for a spatial resolution of $1^{\circ} \times 1^{\circ}$ for each country. We have extracted the data corresponding to the countries that are in the interest domain of study. Note that EDGAR-v3.2 and EDGAR-v4 versions do not contain data for desert aerosols. Therefore, the desert aerosol data are estimated from our simulation with the MB95 model. The model gives the total flux of dust particles with a diameter of less than $20 \mu \mathrm{m}$ without specifying the distribution of the particles according to their sizes. To solve the problem of the distribution of emissions in the different sizes, we used the statistical parameters of the size distribution proposed by Alfaro and Gomes [22] in their Dust Production Model (DPM). This model is used to calculate the emission fluxes and size distribution of particles emitted from a soil by the saltation and sandblasting processes. Alfaro and Gomes [22] have shown that the particle size of a mass of dust particle through a desert source region can be represented by three lognormal modes center on particle diameters of 1.5; 6.7 and $14.2 \mu \mathrm{m}$ (Table 1 ). From the parameters of Table 1, we found by a detailed method exhibited in Nana [5], the emission percentage of each diameter class in the total emissions by summing up the contribution of each diameter within the limits of the class, as presented in Table 2. Thus to obtain the desert aerosol emissions in each class of diameters, the total emission has been multiplied by the percentage of each class of Table 2. These emissions distribution is used as input data to the Polair3D-SIREAM model for the study of dispersion.

Biogenic emissions are constituted of Terpenes (separated into $\alpha$-pinene (67\%) and Limonene (33\%)), Isoprenes and nitrogen monoxide (NO). Sea salt emissions are calculated according to Monahan et al. [55] model. Sea salt emissions are made up of sodium $\left(\mathrm{Na}^{+}\right)$, chloride $\left(\mathrm{Cl}^{-}\right)$, and sulphate $\left(\mathrm{SO}_{4}^{-2}\right)$. They are distributed (in the model) according to of their sizes.

Table 1. Statistical parameters of a given mass, size distribution of dust particles in an emission source according to Alfaro and Gomes [22].

\begin{tabular}{cccc}
\hline & Median mass diameter & Standard deviation & Total mass percentage \\
\hline Mode 1 & $($ Dmedj $), \mu \mathrm{m}$ & $\left(\sigma_{j}\right)$ & $\left(P_{j}\right)$ \\
Mode 2 & 1.5 & 1.7 & 2 \\
Mode 3 & 6.7 & 1.6 & 27 \\
\end{tabular}

Table 2. Contribution of each particle class in the emissions (\%). In our simulation, only the $\mathrm{PM}_{10}$ are considered, then only a fraction of the total emissions is considered.

\begin{tabular}{ccccc}
\hline $\mathrm{PMD}_{0}$ & $\mathrm{PMD}_{1}$ & $\mathrm{PMD}_{2}$ & $\mathrm{PMD}_{3}$ & $\mathrm{PMD}_{4}$ \\
\hline $7.92 \mathrm{E}-13$ & $1.86 \mathrm{E}-5$ & 0.10 & 2.06 & 35.28 \\
\hline
\end{tabular}


The initial and boundary conditions are derived from the global model MOZART-4/GEOS-5. The data MOZART-4/GEOS-5 are provided with a $1.9^{\circ} \times$ $2.5^{\circ}$ horizontal resolution and 56 vertical levels (https://www2.acom.ucar.edu/gcm/mozart-4).

\subsubsection{Observational Data}

$\mathrm{PM}_{10}$ observational data are obtained during the measurement campaign of AMMA project in the Sahel (http://amma-international.org/). There were several measurement sites, but we selected the Banizoumbou (Niger) and Cinzana (Mali) sites that are in the study domain. We extracted the data of year 2007 (daily frequency) which is also the reference year of the simulations. We chose the year 2007 for our simulations because it is the year where the air quality campaign in the city of Ouagadougou was carried out. Details of the AMMA campaign can be found in Marticorena et al. [35]. We also used the observational data of $\mathrm{PM}_{10}$ from measurement campaign performed in Ouagadougou. This measurement campaign took place in 2007 over a period of five months, from February to June. For this campaign, two sites were chosen: a peak site (near traffic) and a background site (near housing). Two 24-hour measurements were taken each month during the five months of measurement. This campaign was financed by the World Bank as part of the project: Clean Air Initiative. The results of the campaign are found in Nana et al. [56].

The aerosols optical thicknesses (AOT) were estimated from the $\mathrm{PM}_{10}$ concentrations modelled with the Polair3d-SIREAM. These estimated AOT data were evaluated with the observational data from the AERONET network. The five stations of AERONET network of the domain are Cinzana (Mali), Agoufou (Mali), Banizoumbou (Niger), Ilorin (Nigeria), Ouagadougou (Burkina Faso) (Figure 1).

\subsubsection{Statistical Indicators}

To evaluate the performance of the model in relation to the observations, we use the following statistical parameters: the Root Mean Square Error (RMSE) to estimate the error compiled (in absolute value) by the model. The correlation between the measurements and the model results is given by the regression coefficient (R). The Normalized Mean Error (NME) (included between $0 \%$ and $+\infty$ quantifies the average error of the modelled data compared to the observation data. The Normalised Mean Bias (NMB) (included between $-100 \%$ and $+\infty$ evaluates the model over-estimates (in case the bias is positive) or underestimates (in case the bias is negative) of the observed values. In addition to these statistical indicators, Boylan and Russel [57] suggested two other indicators that are more robust and less biased for the evaluation of simulations of the particles. These are the mean fractional error (MFE) (between $-200 \%$ and $+200 \%$ ) and the mean fractional bias (MFB) (between 0\% and 200\%). For PM, Boylan and Russel [57] suggested that the performance goal is met if both MFB $\leq \pm 30 \%$ and MFE $\leq$ $50 \%$, and that the model performance criterion is met if both MFB $\leq \pm 60 \%$ and MFE $\leq 75 \%$. Table 3 defines these different statistical indicators. 
Table 3. Defnition of the statistical indicators ( $o_{\dot{P}}$ : observed value, $s_{\dot{F}}$ : modelled value, $\bar{o}$ : observed average, $\bar{s}$ : modelled average, $n$ number of data).

\begin{tabular}{cc}
\hline Indicators & Definition \\
\hline Root Mean Square Error (RMSE) & $\frac{1}{n} \sum_{i=1}^{n} \frac{s_{i}-o_{l}}{\left(s_{i}+o_{l}\right) / 2}$ \\
Correlation Coefficient (R) & $\frac{\sum_{i=1}^{n}\left(o_{i}-\bar{o}_{l}\right)\left(s_{i}-\bar{s}_{l}\right)}{\sqrt{\sum_{i=1}^{n}\left(o_{i}-\bar{o}_{l}\right)^{2} \times \sum_{i=1}^{n}\left(s_{i}-\overline{s_{l}}\right)^{2}}}$ \\
Normalized Mean Error (NME) & $\frac{\sum_{i=1}^{n}\left(s_{i}-o_{l}\right)}{\sum_{i=1}^{n} o_{i}}$ \\
Normalized Mean Bias (NMB) & $\frac{\sum_{i=1}^{n}\left(s_{i}-o_{l}\right)}{\sum_{i=1}^{n} o_{i}}$ \\
Mean Fractional Bias (MFB) & $\frac{1}{n} \sum_{i=1}^{n} \frac{\left|s_{i}-o_{i}\right|}{\left(s_{i}+o_{i}\right) / 2}$ \\
Mean Fractional Error (MFE) & $\frac{1}{n} \sum_{i=1}^{n} \frac{\left|s_{i}-o_{i}\right|}{\left(s_{i}+o_{i}\right) / 2}$ \\
\hline
\end{tabular}

\section{Results and Discussions}

\subsection{Emission of Dust}

Figure 2 presents the dust emissions in the study domain. By calculating the total amount of dust emissions, we obtain $56.2 \mathrm{Tg}$ for the year 2007. This value remains in the order of magnitude of dust emissions calculated in North Africa according to the compilation of Engelstaedter et al. [11], presented in Table 4. However, it should be noted here that our domain is not the same as the calculated emissions domain in Table 4. The areas where the emissions are the most important are between latitudes $15^{\circ} \mathrm{N}$ and $24^{\circ} \mathrm{N}$. This zone also corresponds to the one found by many authors Marticorena and Bergametti [58], Laurent et al. [10], Goudie and Middleton [29], Schmechtig et al. [32] to be the most important emission zone. The high emissions, at coordinates around $7^{\circ} \mathrm{W}$ of longitude and between latitudes $16^{\circ}$ to $20^{\circ} \mathrm{N}$ correspond to high surface winds, as presented (see Figure 3). These dust emissions are used for the Polair3D dispersion model. Note that we have modelled the dust emissions using wind speeds from the ECMWF database without modification. Schmechtig et al. [32] and Song et al. [59] showed that dust emissions are the most related to surface winds.

\subsection{Evaluation of $\mathrm{PM}_{10}$ Simulated}

This section presents the results of the simulations obtained with Polair3D-SIREAM. These results are compared with observational data by using statistical indicators. Table 5 exhibits the result of the statistical evaluation. One can notice that the simulated averages are in the same order of magnitude as the averages observed for almost all sites. However, the model simulated values are slightly underestimated compared to the observed values for the Banizoumbou and Cinzana stations. On the other hand, the simulated values are slightly overestimated 
compared to the values observed for the two stations of Ouagadougou. The correlation coefficients are overall low and range from 5.6\% to $15.8 \%$. Schmechtig et al. [32] obtained better correlation coefficients that were ranged from $45 \%$ to $58 \%$. The worse correlations in this study can be explained by the correction of surface winds performed in Schmechtig et al. [32]. In our case, we used the ECMWF surface winds without correction. It would be interesting in perspective to correct surface winds velocity with the method of Schmechtig et al. [32]. The other statistical parameters are $67 \% \leq \mathrm{NME} \leq 83.4 \% ;-44 \% \leq \mathrm{NMB} \leq 4 \% ; 64 \% \leq$ MFE $\leq 86 \% ; 19 \% \leq$ MFB $\leq 44 \%$. In Table 6, we compared these statistical indicators with the results of Schmechtig et al. [32] derived for the same sites (Banizoumbou and Cinzana). We notice that the NME, NMB, MFE and MFB indicators are the same order of magnitude in both studies. Our values are slightly better than those of Schmechtig et al. [32]. For the performance criteria of Boylan and Russel [57], they are met for the Cinzana and Ouagadougou sites and not achieved for the Banizoumbou site. Performance goals are not met for all sites.

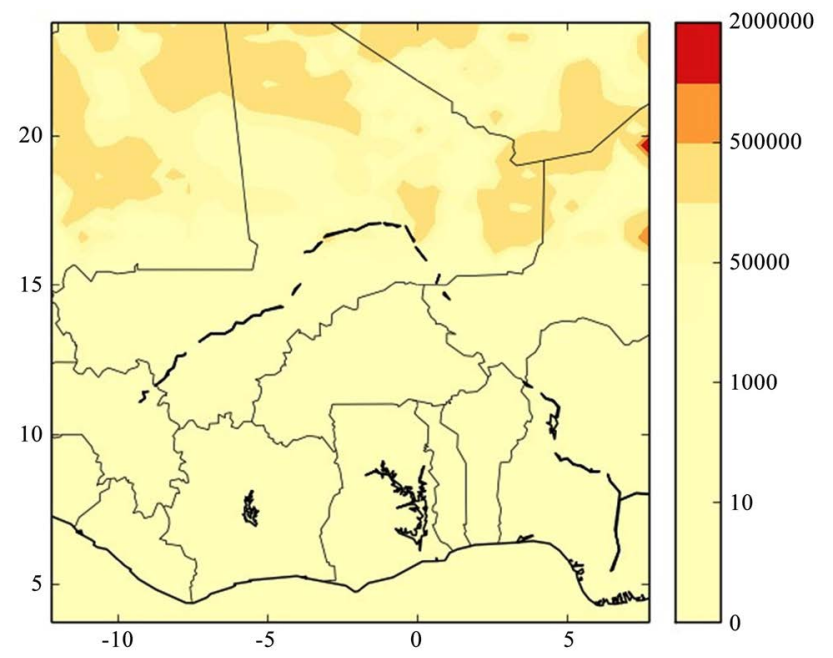

Figure 2. Dust emission estimated using MB95 model for the simulation domain (in tons).

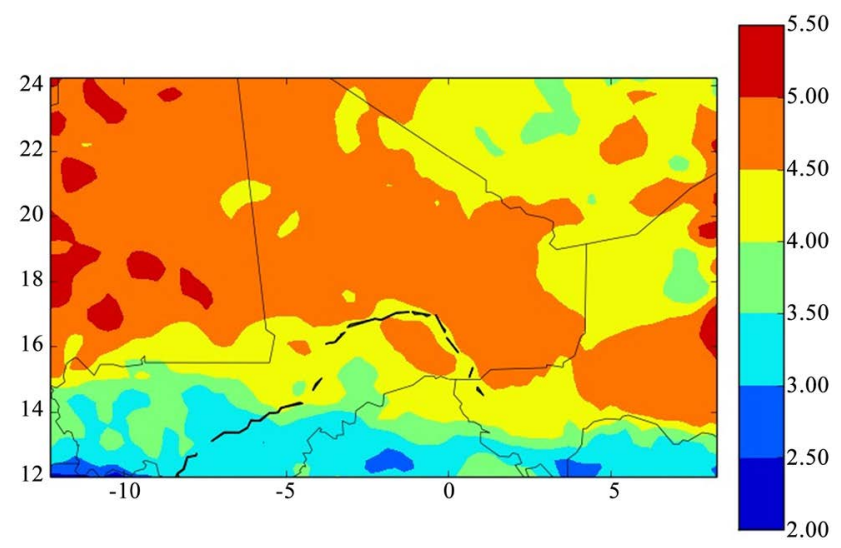

Figure 3. Wind average used to calculate dust emission (in $\mathrm{m} \cdot \mathrm{s}^{-1}$ ). 
Table 4. Estimates of mean annual dust emission (E) for North Africa. The data compilation is based on the works of Middleton and Goudie [29], Zender et al. [31] andMahowald et al. [30]. The estimate is based on the sum of emissions from the individualsource regions (W. Africa, C. Africa and E. Africa).

\begin{tabular}{cc}
\hline References & E for North Africa $\left(\mathrm{Tg} \cdot \mathrm{yr}^{-1}\right)$ \\
\hline Schütz et al. (1981) [60] & 260 \\
Miller et al. (2004) [12] & $479-589$ \\
Ginoux et al. (2004) [13] & 1430 \\
Marticorena and Bergametti [58] & $586-665$ \\
Prospero (1996) [61] & 170 \\
Swap et al. (2000) [62] & $130-460$ \\
Ozer (2001) [63] & 1600 \\
Callot et al. (2000) [43] & 760 \\
Kaufman et al. (2005) [64] & 240 \\
Laurent et al. (2008) [10] & $580-760$
\end{tabular}

Table 5. Polair3D-SIREAM performance evaluation with surface $\mathrm{PM}_{10}$ concentrations atAMMA observation sites (Banizoumbou et Cinzana) and Ouagadougou observation sites (background and peak sites of Ouagadougou).

\begin{tabular}{ccccccccc}
\hline \multirow{2}{*}{ Observation sites } & MeanObs & MeanSim & RMSE & $\mathrm{R}$ & NME & NMB & MFE & MFB \\
\cline { 2 - 8 } & $\left(\mu \mathrm{g} \cdot \mathrm{m}^{-3}\right)$ & $\left(\mu \mathrm{g} \cdot \mathrm{m}^{-3}\right)$ & $\left(\mu \mathrm{g} \cdot \mathrm{m}^{-3}\right)$ & $(\%)$ & $(\%)$ & $(\%)$ & $(\%)$ & $(\%)$ \\
\hline $\begin{array}{c}\text { Daily-Banizoumbou } \\
\text { Daily-Cinzana }\end{array}$ & 259.1 & 245.0 & 347.6 & 15.8 & 83.4 & -5.4 & 86 & 44 \\
$\begin{array}{c}\text { Hourly-Background } \\
\text { Ouagadougou }\end{array}$ & 166.6 & 239.8 & 158.2 & 5.6 & 81.9 & -44.0 & 68 & 42 \\
$\begin{array}{c}\text { Hourly-Peak } \\
\text { Ouagadougou }\end{array}$ & 231.9 & 241.3 & 219.5 & 13.7 & 67.0 & 4.0 & 64 & 19 \\
\hline
\end{tabular}

Table 6. Comparison of statistic indicators from Schmechtig et al. [32] and this study. Daily concentration of $\mathrm{PM}_{10}$ are used to estimate the statistic indicators.

\begin{tabular}{cccccc}
\hline Observation sites & R (\%) & NME (\%) & NMB (\%) & MFE (\%) & MFB (\%) \\
\hline $\begin{array}{c}\text { Banizoumbou } \\
\text { (Schmechtig } \text { et al. [32]) }\end{array}$ & 55 & 96 & -3 & 82 & -49 \\
Banizoumbou (this study) & 15.8 & 83.4 & -5.4 & 86 & 44 \\
Cinzana (Schmechtig et al. [32]) & 58 & 75 & -36 & 86 & -53 \\
Cinzana (this study) & 9.4 & 69 & -15.1 & 70 & 19 \\
\hline
\end{tabular}

Figures 4(a)-(d), presents the dispersion diagrams on all sites. These diagrams show the low correlations already observed in Table 5. In addition, it is generally observed that for $\mathrm{PM}_{10}$ concentrations between 0 and $200 \mu \mathrm{g} \cdot \mathrm{m}^{-3}$, the simulated values are higher than the observed values. For concentrations above $200 \mu \mathrm{g} \cdot \mathrm{m}^{-3}$, the observed values are higher than the simulated values. 


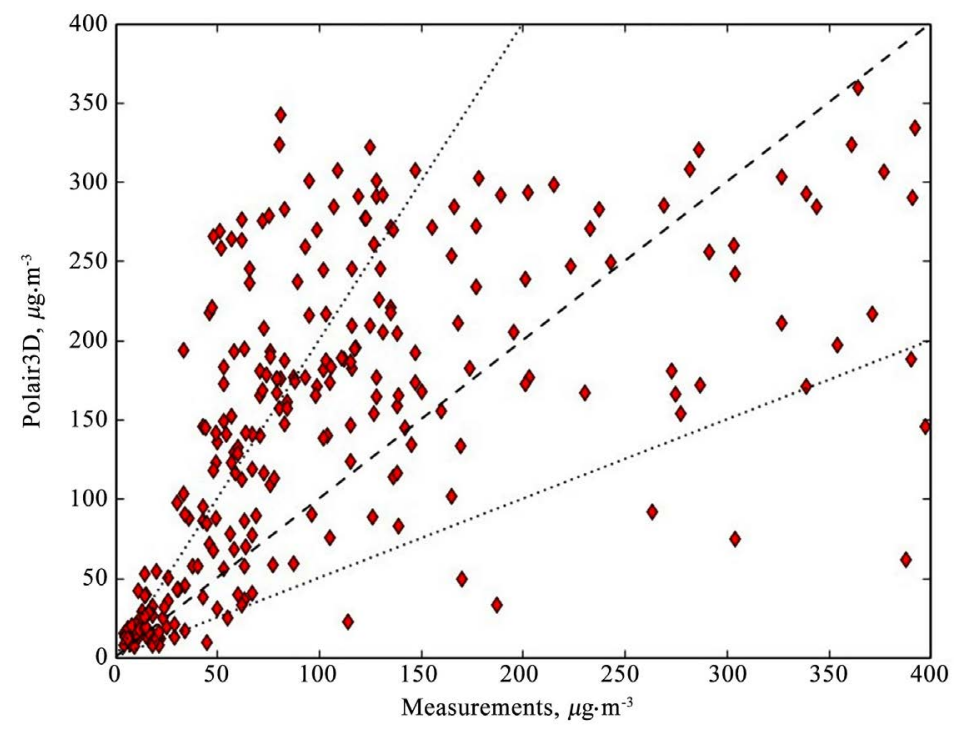

(a)
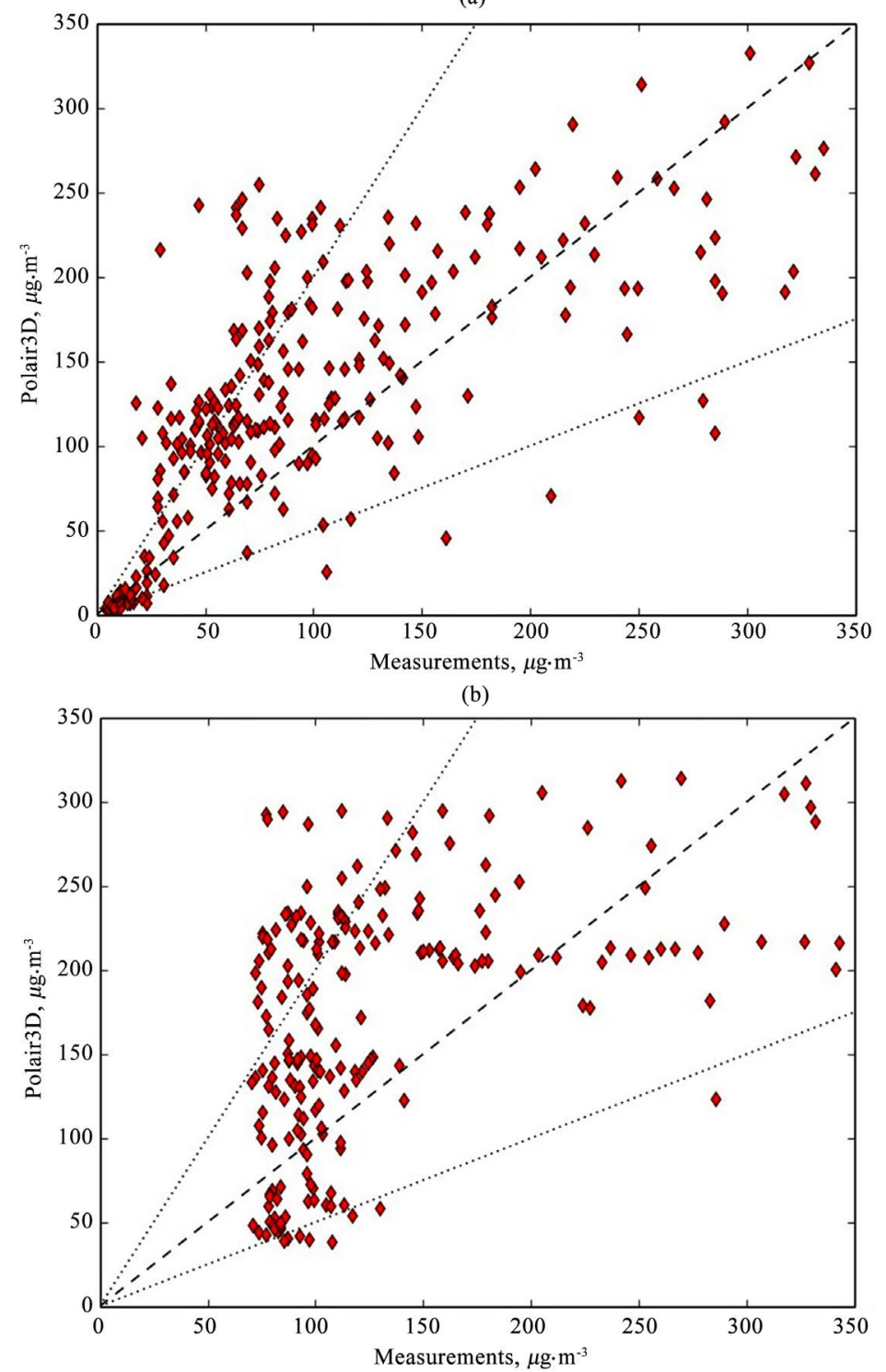

(c) 


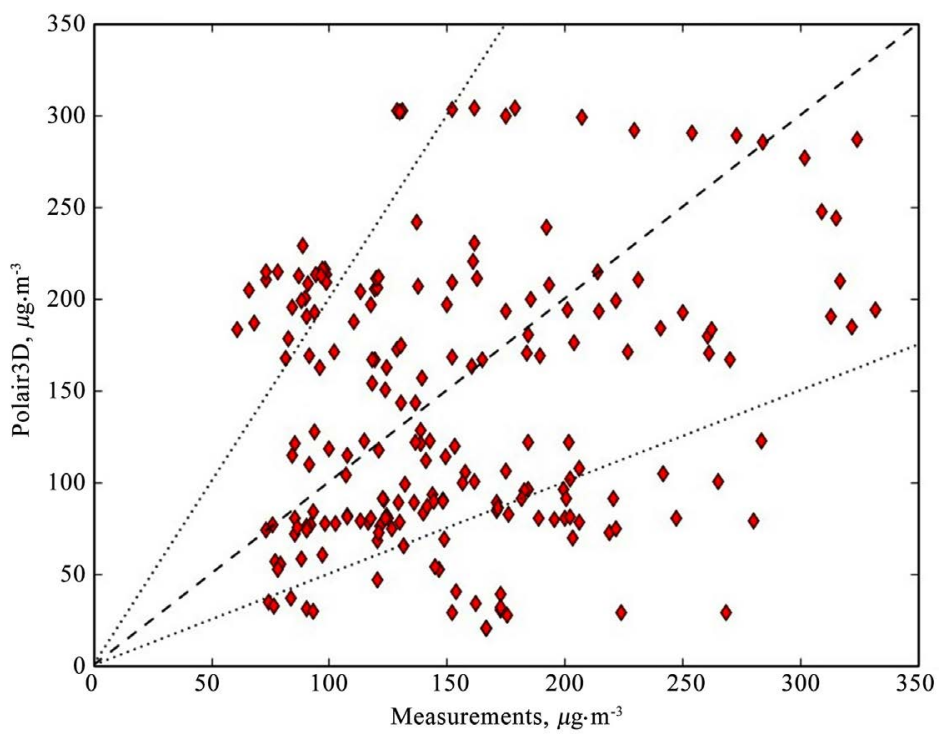

(d)

Figure 4. Scatter plots from all stations: (a) Banizoumbou (Niger), (b) Cinzana (Mali), (c) Background Ouaga (Burkina Faso), (d) PeackOuaga (Burkina Faso).

Figures 5(a)-(d) presents the comparison of the temporal evolution between the simulated and observed values for the measurement stations. High concentrations of $\mathrm{PM}_{10}$ are observed from November to July and low concentrations are observed from August to October at almost all sites, because of the rainy season. However, for the sites of Ouagadougou, there is no measurement from July to December. This temporal evolution has also been observed in the work of Schmechtig et al. [32], Laurent et al. [10], and Marticorena and Bergametti [9]. We also notice that for periods of high concentrations, the observed values are well above those of simulated values.

\subsection{Evaluation of Aerosol Optical Thickness}

The purpose of the evaluation with aerosol optical thicknesses is to verify that the underestimation of surface $\mathrm{PM}_{10}$ concentrations is not a problem of dispersion. AOT are estimated from simulated $\mathrm{PM}_{10}$ concentrations at five vertical levels. We present below in Table 7, the results of the evaluation. The simulated averages of AOT are slightly higher than the averages observed for all the sites except for Ouagadougou. The correlation coefficients obtained for the simulated and observed AOTs are significantly better than those of the simulated and observed surface $\mathrm{PM}_{10}$ concentrations. These coefficients are between $37.4 \%$ and $67.2 \%$. This better correlation can be explained by the low influence of surface winds at height. Indeed, Schmechtig et al. [32] and Menut et al. [65] explained that global meteorological models are not able to reproduce surface winds well enough, which is a source of error in simulated dust concentrations on the ground. We also note that the correlations for Ilorin (67.2\%), Agoufou (52.2\%), Ouagadougou (52\%), are better than those for Banizoumbou (37.4\%) and Cinzana (49.6\%). The latter sites (Banizoumbou and Cinzana) are closer to the main 


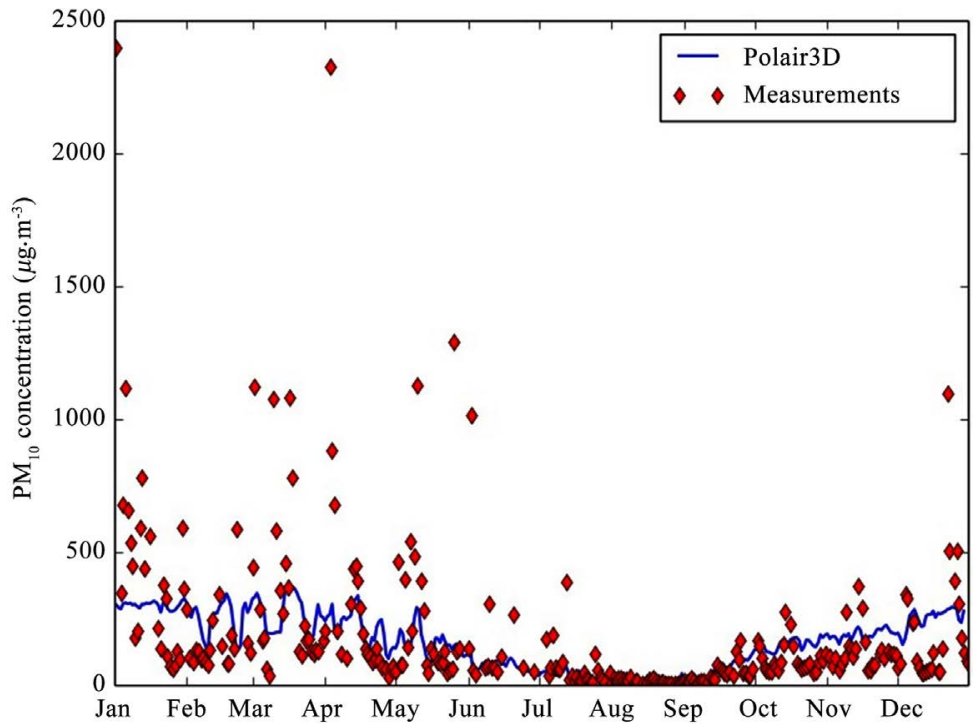

(a)

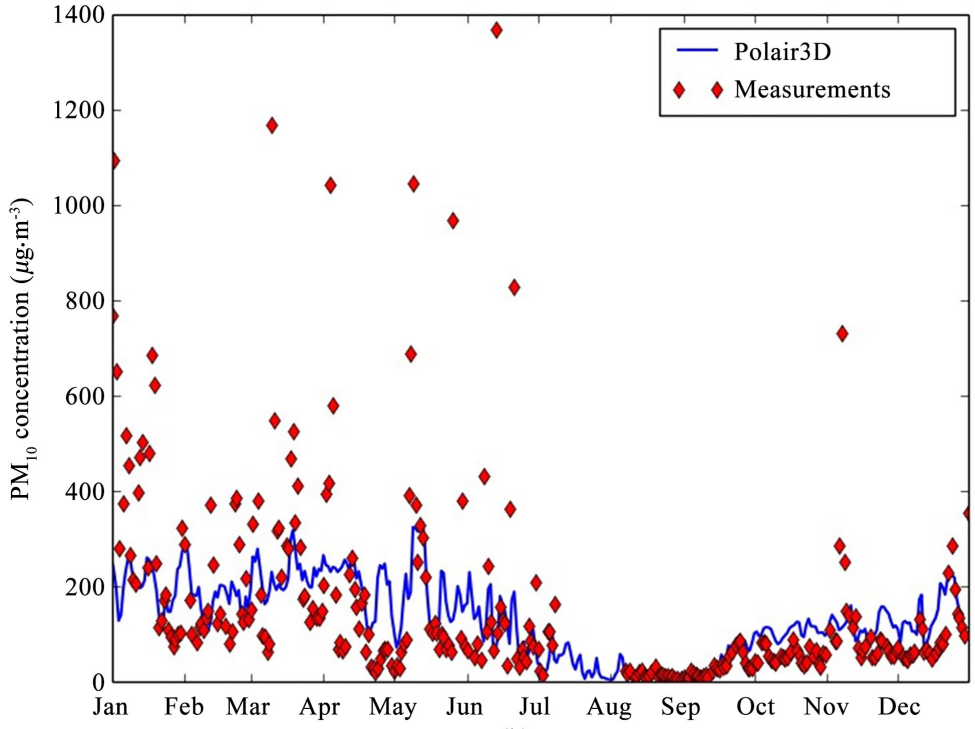

(b)

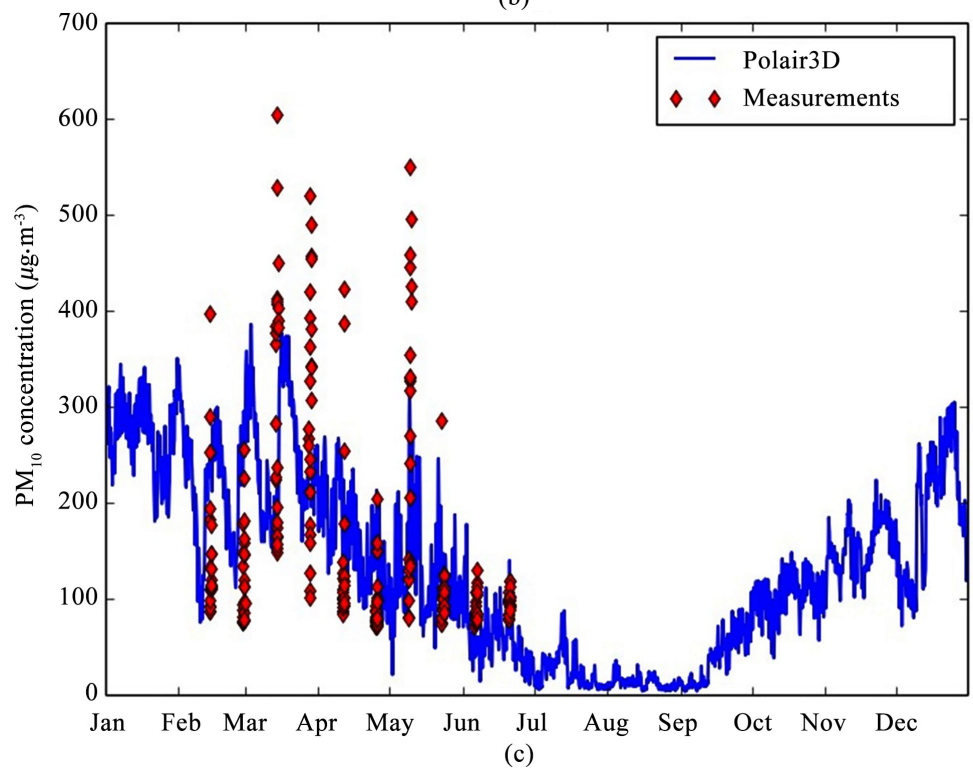




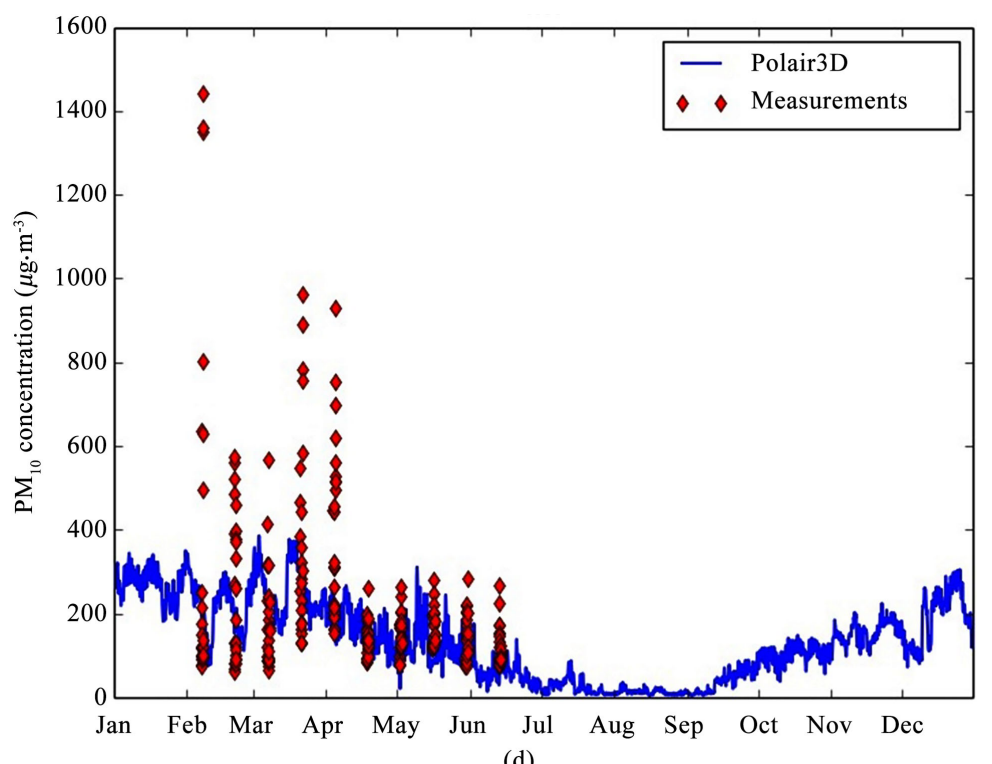

Figure 5. Series of observed (red lozenges) and simulated (blue lines) $\mathrm{PM}_{10}$ concentrations at 4 sites: (a) Banizoumbou, (b) Cinzana (Mali), (c) Background Ouagadougou (Burkina Faso), (d) Peack Ouagadougou (Burkina Faso).

Table 7. Statistics obtained by comparing AOT data $(\lambda=550 \mathrm{~nm})$ calculated from output data simulated by Polair3D-SIREAM and data from AERONET observation stations (Daily observations).

\begin{tabular}{ccccccccc}
\hline \multirow{2}{*}{ Observation sites } & MeanObs & MeanSim & RMSE & $\mathrm{R}$ & NME & NMB & MFE & MFB \\
\cline { 2 - 8 } & $\left(\mu \mathrm{g} \cdot \mathrm{m}^{-3}\right)$ & $\left(\mu \mathrm{g} \cdot \mathrm{m}^{-3}\right)$ & $\left(\mu \mathrm{g} \cdot \mathrm{m}^{-3}\right)$ & $(\%)$ & $(\%)$ & $(\%)$ & $(\%)$ & $(\%)$ \\
\hline Agoufou & 0.6 & 0.8 & 0.5 & 52.2 & 70.9 & 46 & 65 & 53 \\
Banizoumbou & 0.6 & 0.8 & 0.5 & 37.4 & 66.2 & 30 & 59 & 35 \\
Cinzana & 0.5 & 0.7 & 0.4 & 49.6 & 57.6 & 32 & 52 & 33 \\
Ilorin & 0.8 & 0.8 & 0.4 & 67.2 & 36 & -1 & 40 & -2 \\
Ouagadougou & 1.2 & 1.1 & 0.6 & 52.9 & 39 & -7 & 42 & 8 \\
\hline
\end{tabular}

sources of dust emissions than the other sites i.e. Ilorin and Ouagadougou. Schmechtig et al. [32] have concluded that correlations between simulated and observed AOT values are better when the observation site is further away from the main sources of dust emissions. In general, we notice that the other statistical indicators in Table 7 (for AOTs) are significantly better than those in Table 5 (surface concentrations of $\mathrm{PM}_{10}$ ). The statistical scores in Table 7 are significantly better for Ilorin ( $\mathrm{R}=67.2 \%, \mathrm{NME}=36 \%, \mathrm{NMB}=-1 \%, \mathrm{MFE}=40 \%, \mathrm{MFB}$ $=-2 \%)$ and Ouagadougou $(\mathrm{R}=52.9 \%, \mathrm{NME}=39 \%, \mathrm{NMB}=-7 \%$, $\mathrm{MFE}=42 \%$, $\mathrm{MFB}=8 \%)$ than those of Agoufou $(\mathrm{R}=52.2 \%, \mathrm{NME}=70.9 \%, \mathrm{NMB}=46 \%$, $\mathrm{MFE}=65 \%, \mathrm{MFB}=53 \%)$ Banizoumbou $(\mathrm{R}=37.4 \%, \mathrm{NME}=66.2 \%, \mathrm{NMB}=$ $30 \%, \mathrm{MFE}=59 \%, \mathrm{MFB}=35 \%)$ and Cinzana $(\mathrm{R}=49.6 \%, \mathrm{NME}=57.6 \%, \mathrm{NMB}=$ $32 \%, \mathrm{MFE}=52 \%, \mathrm{MFB}=33 \%$ ) because of their longer distance away from the 
main sources of dust emissions. By comparing the statistical scores of Schmechtig et al. [32] for AOTs from the Banizoumbou $(\mathrm{R}=44 \%, \mathrm{NME}=82 \%, \mathrm{NMB}=$ $12 \%, \mathrm{MFE}=75 \%, \mathrm{MFB}=-31 \%)$ and Cinzana $(\mathrm{R}=49.4 \%, \mathrm{NME}=74 \%, \mathrm{NMB}=$ $-14 \%, \mathrm{MFE}=73 \%, \mathrm{MFB}=-41 \%)$ with our scores for the same sites, we notice that our NME and MFE values are better. On the other hand, the values of NMB, MFB of Schmechtig et al. [32] are better than ours. However, the correlations are approximately the same in both studies. In the evaluation of Table 7, the performance goals of Boylan and Russel [57] are met for the Ilorin and Ouagadougou sites and not met for Agoufou, Banizoumbou and Cinzana. On the other hand, the performance criteria of Boylan and Russel [57] are met for all sites.

Figures 6(a)-(e) presents the temporal evolution of AOT values at the different sites. We observe that the temporal profiles of the simulated values are very similar to those of the observations with a first period of high values between February and May and a second period in November and December. As a result, high AOT values are observed in the dry season and low values in the rainy season. This temporal variation was observed by Marticorena et al. [35], Schmechtig et al. [32]. We notice that the maximum measured values are between 3.5 (Cinzana and Ilorin) and 4 (Banizoumbou and Agoufou) while the simulated values by the model are around 1.5 for almost all sites. We notice that the model does not succeed in reproducing the peaks of AOT values which are often due to local dust inputs caused by high surface winds and therefore difficult to be represented by the meteorological models (Schmechtig et al. [32]; Menut et al. [65]).

\section{Conclusion and Perspectives}

In this study, we tested the ability of Polair3D-SIREAM to reproduce the desert aerosols observations in our study domain. The MB95 model (Marticorena and Bergametti [9]) was used to estimate dust emissions. We used the observations data of surface $\mathrm{PM}_{10}$ of the AMMA measurement campaign and the observation data of AOT from the AERONET network for validation. Our results were compared with those of Schmechtig et al. [32]. The comparison between simulations and observations was with statistical indicators commonly used to evaluate the performance of air quality models.

The total emission of dust modelled in our domain is $52.2 \mathrm{Tg}$ for the year 2007. For the evaluation of the Polair3D-SIREAM model with $\mathrm{PM}_{10}$ observations; we obtained low correlation coefficients (5.6\% to $15.8 \%$ ) at all observation sites which are lower than those obtained by Schmechtig et al. [32]. For the other statistical indicators, we obtained better results than those of Schmechtig et al. [32]. The criteria of performance of Boylan and Russel [57] are achieved for the observation sites of Ouagadougou and Cinzana and not achieved for Banizoumbou. However, performance goals are not met for all sites. We also obtained that the temporal evolution is well correlated with the observations. High dust values are observed in dry season and low values in rainy season. 

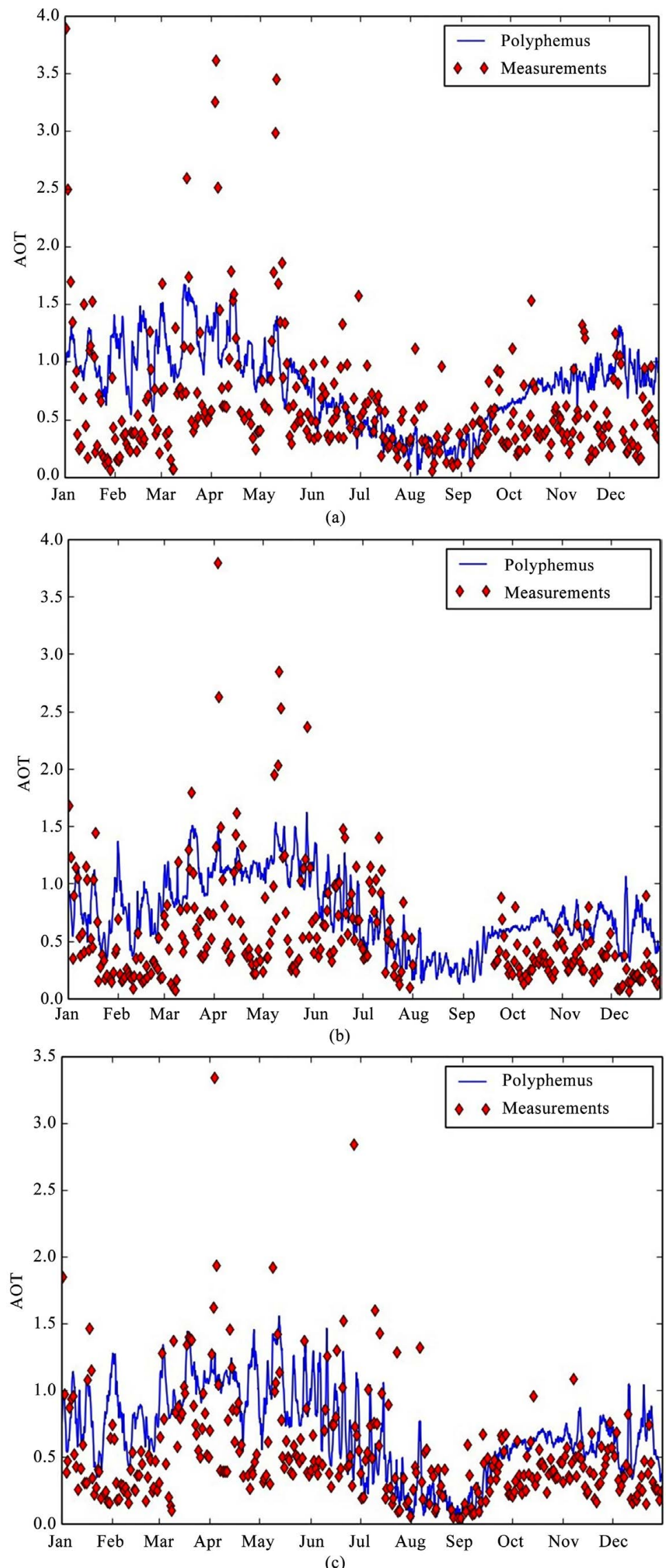


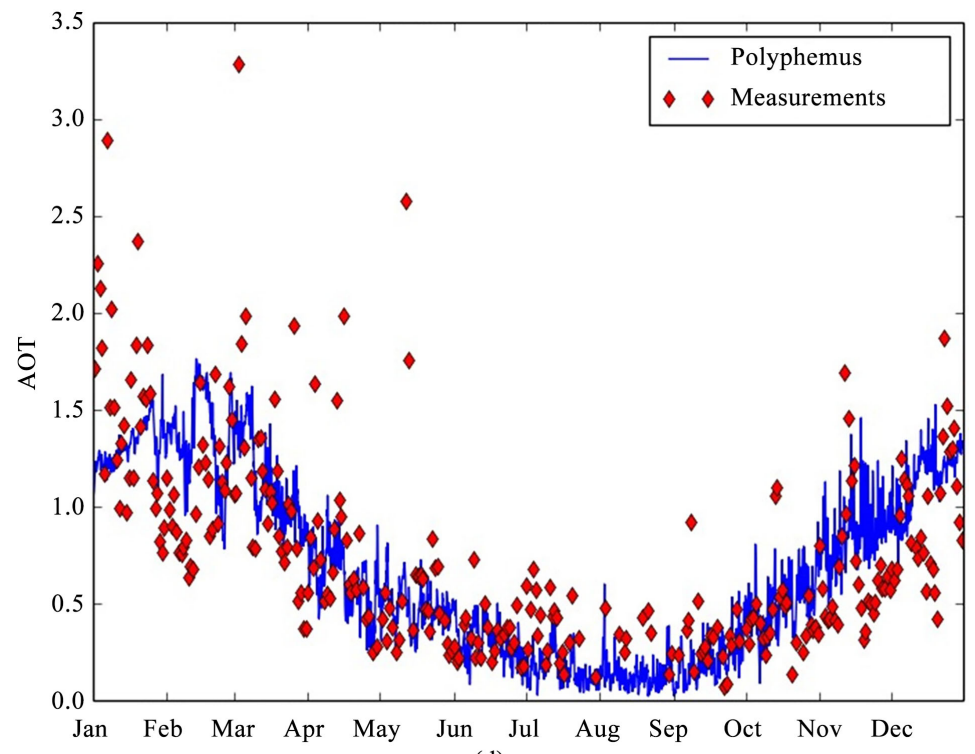

(d)

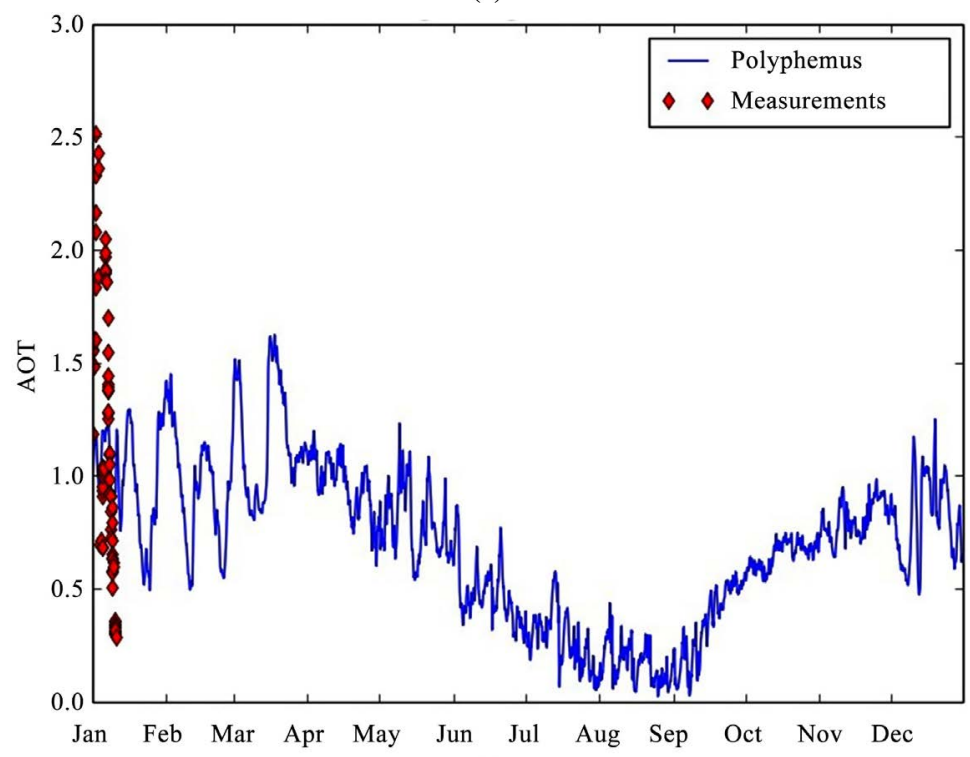

(e)

Figure 6. Series of observed (red lozenges) and simulated (blue lines) AOT at 5 sites: (a) Banizoumbou (Niger), (b) Agoufou (Mali), (c) Cinzana (Mali), (d) Ilorin (Nigeria), (e) Ouagadougou (Burkina Faso).

For validation with AOTs, the model reproduces well the observed values. Correlation coefficients (37.4\% to 67.2\%) are better than those for surface $\mathrm{PM}_{10}$. Better correlations are obtained for Ouagadougou and Ilorin observation sites which are far from the main sources of dust emission. Performance goals and criteria of Boylan and Russel [57] are achieved for the Ouagadougou and Ilorin sites. On the other hand, only performance criteria are met for the Agoufou, Banizoumbou and Cinzana sites.

In the future we will complete the evaluation of Polair3D-SIREAM by investigating its ability to reproduce the deposition fluxes. The results will also be used to provide boundary conditions for a simulation over the city of Ouaga- 
dougou. Through this simulation on a regional scale (West Africa), we can generate the initial and boundary conditions of the local scale (Ouagadougou) that was the objective of this study.

\section{Acknowledgements}

We thank the French cooperation in Burkina Faso, who granted a study trip to the laboratory CEREA, during the doctoral thesis of Nana Bernard. We also wish to thank the Institute of Science (IDS) for funding the completion of the research. We would like to thank Yelva Roustan and Youngseob Kim of CEREA who enabled us to solve all problems during the study.

\section{Conflicts of Interest}

The authors declare no conflicts of interest regarding the publication of this paper.

\section{References}

[1] WHO (2015) Health in 2015: From MDGs to SDGs. Technical Report. World Health Organization. http://www.who.int/gho/publications/mdgs-sdgs/en/

[2] Tractebel (1999) Etude de la qualité de l'air Ouagadougou. Technical Report. Sub-Saharan Africa Transport Policy Program, SSATP, Etude réalisée par "Tractebel Development Engineering” pour le compte de la composante mobilité urbaine du SSATP.

[3] BM (1999) Etude de la qualité de l'air en milieu urbain: Cas de Dakar et Ouagadougou. Technical Report. Banque Mondiale, Programme de politiques de transports en Afrique Subsaharienne, $52 \mathrm{p}$.

[4] Worou, C.T. (2005) Pollution Atmosphérique au Bénin: Cas de Cotonou. Technical Report. Ministère de l'Environnement de l'Habitat et de l'Urbanisme, Bénin.

[5] Nana, B. (2011) Pollution atmosphérique en Afrique de l'Ouest: Mesure et modélisation. Ph.D. Thesis, Université de Ouagadougou, Burkina Faso.

[6] CREPA (1994) Etude sur la pollution atmosphérique dans la ville de Ouagadougou, Technical Report, Centre Regional pour l'Eau Potable et l'Assainissement, Ministère de l'Environnement et du tourisme.

[7] Formenti, P., Rajot, J.L., Desboeufs, K., Caquineau, S., Nava, S.C.S., Gaudichet, A., Journet, E., Triquet, S., Alfaro, S., Chiari, M., Haywood, J., Coe, H. and Highwood, E., (2008) Regional Variability of the Composition of Mineral Dust from Western Africa: Results from the AMMA SOP0/DABEX and DODO Field Campaigns. Journal of Geophysical Research, 113, 1-12. https://doi.org/10.1029/2008JD009903

[8] Kandler, K., Benker, N., Bundke, U., Cuevas, E., Ebert, M., Knippertz, P., Rodrguez, S., Schtz, L. and Weinbruch, S. (2007) Chemical Composition and Complex Refractive Index of Saharan Mineral Dust at Izaa, Tenerife (Spain) Derived by Electron Microscopy. Atmospheric Environment, 41, 8058-8074.

[9] Marticorena, B. and Bergametti, G. (1995) Modeling the Atmospheric Dust Cycle: 1. Design of a Soil Derived Dust Production Scheme. Journal of Geophysical Research, 100, 16415-16430. https://doi.org/10.1029/95JD00690

[10] Laurent, B., Marticorena, B., Bergametti, G., Léon, J.F. and Mahowald, N.M. (2008) Modeling Mineral Dust Emission from the Sahara Desert Using New Surface Prop- 
erties and Soil Database. Journal of Geophysical Research, 113, 1-20.

[11] Engelstaedter, S., Tegen, I. and Washington, R. (2006) North African Dust Emissions and Transport. Earth-Science Reviews, 79, 73-100.

https://doi.org/10.1016/j.earscirev.2006.06.004

[12] Miller, R.L., Perlwitz, J. and Tegen, I. (2004) Feedback upon Dust Emission by Dust Radiative Forcing through the Planetary Boundary Layer. Journal of Geophysical Research, 109, D24209. https://doi.org/10.1029/2004JD004912

[13] Ginoux, P., Prospero, J.M., Torres, O. and Chin, M., (2004) Long-Term Simulation of Global Dust Distribution with the GOCART Model: Correlation with North Atlantic Oscillation. Environmental Modelling \& Software, 19, 113-128. https://doi.org/10.1016/S1364-8152(03)00114-2

[14] Formenti, P., Schütz, L., Balkanski, Y., Desboeufs, K., Ebert, M., Kandler, K., Petzold, A., Scheuvens, D., Weinbruch, S. and Zhang, D. (2011) Recent Progress in Understanding Physical and Chemical Properties of African and Asian mineral dust. Atmos. Chemical Physics, 11, 8231-8256.

[15] Goudie, A. (2008) Dust Storms: Recent Developments. Journal of Environmental Management, 90, 89-94. https://doi.org/10.1016/j.jenvman.2008.07.007

[16] Lambert, F., Kug, J., Park, R., Mahowald, N., Winckler, G., Abe-Ouchi, A., O’ishi, R., Takemura, T. and Lee, J.H. (2013) The Role of Mineral Dust Aerosols in Polar Temperature Amplification. Nature Climate Change, 3, 487-491. https://doi.org/10.1038/nclimate1785

[17] Gillette, D.A. (1979) Environmental Factors Affecting Dust Emission by Wind Erosion. Wiley and Sons, New York, 71-94.

[18] Shao, Y., Raupach, M.R. and Findlater, P.A. (1993) Effect of Saltation Bombardment on the Entrainment of Dust by Wind. Journal of Geophysical Research, 98, 12,719-12,726. https://doi.org/10.1029/93JD00396

[19] Marticorena, B., Bergametti, G., Aumont, B.Y.C., N’Doumé, C. and Legrand, M. (1997) Modeling the Atmospheric Dust Cycle: 2. Simulations of Saharan Dust Sources. Journal of Geophysical Research, 102, 4,387-4,404.

[20] Alfaro, S.C., Gaudichet, A., Gomes, L. and Maillé, M. (1997) Modeling the Size Distribution of a Soil Aerosol Produced by Sandblasting. Journal of Geophysical Research, 102, 11239-11249. https://doi.org/10.1029/97JD00403

[21] Alfaro, S.C., Gaudichet, A., Gomes, L. and Maille, M. (1998) Mineral Aerosol Production by Wind Erosion: Aerosol Particle Sizes and Binding Energies. Geophysical Research Letters, 25, 991-994. https://doi.org/10.1029/98GL00502

[22] Alfaro, S.C. and Gomes, L. (2001) Modelling Mineral Aerosol Production by Wind Erosion: Emission Intensities and Aerosol Distributions in Source Areas. Journal of Geophysical Research, 106, 18075-18084. https://doi.org/10.1029/2000JD900339

[23] Gong, S.L., Zhang, X.Y., Zhao, T.L., McKendry, I.G., Jaffe, D.A. and Lu, N.M. (2003) Characterization of Soil Dust Distributions in China and Its Transport during Ace-Asia: 2. Model Simulation and Validation. Journal of Geophysical Research, $108,4262$.

[24] Shao, Y. (2001) A Model for Mineral Dust Emission. Journal of Geophysical Research, 106, 20239-20254. https://doi.org/10.1029/2001JD900171

[25] Shao, Y. (2004) Simplification of a Dust Emission Scheme and Comparison with Data. Journal of Geophysical Research, 109, D10202. https://doi.org/10.1029/2003JD004372

[26] In, H.J. and Park, S.U. (2002) A Simulation of Long Range Transport of Yellow 
Sand Observed in April 1998 in Korea. Atmospheric Environment, 36, 4173-4187.

[27] Laurent, B., Marticorena, B., Bergametti, G. and Mei, F. (2006) Modeling Mineral Dust Emissions from Chinese and Mongolian Deserts. Global and Planetary Change, 52, 121-141. https://doi.org/10.1016/j.gloplacha.2006.02.012

[28] Zhao, T.L., Gong, S.L., Zhang, X.Y., Abdel-Mawgoud, A. and Shao, Y.P. (2006) An Assessment of Dust Emission Schemes in Modeling East Asian Dust Storms. Journal of Geophysical Research, 111.

[29] Goudie, A. and Middleton, N. (2001) Sharan Dust Storms: Nature and Consequences. Earth-Science Reviews, 56, 179-204. https://doi.org/10.1016/S0012-8252(01)00067-8

[30] Mahowald, N., Bergametti, G., Brooks, N., Duce, R.A., Jickells, T.D., Kubilay, N., Prospero, J. and Tegen, I. (2005) Atmospheric Global Dust Cycle and Iron Inputs to the Ocean. Global Biochemical Cycles, 19, GB4025.

[31] Zender, C.S., Miller, R.L. and Tegen, I. (2004) Quantifying Mineral Dust Mass Budget: Terminolgy, Constraints and Current Estimates. EOS, 85, 509-512. https://doi.org/10.1029/2004EO480002

[32] Schmechtig, C., Marticorena, B., Chatenet, B., Bergametti, G., Rajot, J.L. and Coman, A. (2011) Simulation of the Mineral Dust Content over Western Africa from the Event to the Annual Scale with the CHIMERE-DUST Model. Atmospheric Chemistry and Physics, 11, 7185-7207. https://doi.org/10.5194/acp-11-7185-2011

[33] Vautard, R., Beekmann, M., Roux, J. and Gombert, D. (2001) Validation of a Deterministic Forecasting System for the Ozone Concentrations over the Paris. Atmospheric Environment, 35, 2449-2461.

[34] Bessagnet, B., Hodzic, A., Vautard, R., Beekmann, M., Cheinet, S., Honoré, C., Liousse, C. and Rouil, L. (2004) Aerosol Modeling with CHIMERE-Preliminary Evaluation at the Continental Scale. Atmospheric Environment, 38, 2803-2817. https://doi.org/10.1016/j.atmosenv.2004.02.034

[35] Marticorena, B., Chatenet, B., Rajot, J.L., Traore, S., Coulibaly, M., Diallo, A., Koné, I., Maman, A., N’Diaye, T. and Zakou, A. (2010) Temporal Variability of Mineral Dust Concentrations over West Africa: Analyses of a Pluriannual Monitoring from the Amma Sahelian Dust Transect. Atmospheric Chemistry and Physics, Discussions, 10, 8051-8101.

[36] Olivier, J.G.J., Bouwman, A.F., van der Maas, C.W.M. and Berdowski, J.J.M. (1994) Emission Database for Global Atmospheric Research (EDGAR). Environmental Monitoring and Assessment, 31, 93-106. https://doi.org/10.1007/BF00547184

[37] Olivier, J.J.B., Peters, J., Bakker, J., Visschedijk, A. and Bloos, J. (2001) Applications of EDGAR. Including a Description of EDGAR 3.0: Reference Database with Trend Data for 1970-1995. Technical Report, National Institute for Public Health and the Environment (RIVM), Netherlands Organisation for Applied Scientific Research (TNO).

[38] Laurent, B. (2006) Simulation des émissions d'aérosols désertiques l'échelle continentale: Analyse climatologique des émissions du Nord-Est de l'Asie et du nord de l'Afrique. Ph.D. Thesis, Université Paris 12.

[39] White, B.R. (1979) Soil Transport by Winds on Mars. Journal of Geophysical Research, 84, 4643-4651. https://doi.org/10.1029/JB084iB09p04643

[40] Fécan, F., Marticorena, B. and Bergametti, G. (1999) Parameterization of the Increase of the Aeolian Erosion Threshold wind Friction Velocity Due to Soil Moisture for Semi-Arid Areas. Annals of Geophysics, 17, 149-157. 
https://doi.org/10.1007/s005850050744

[41] Marticorena, B., Chazette, P., Bergametti, G., Dulac, F. and Legrand, M. (2004) Mapping the Aerodynamic Roughness Length of Desert Surfaces from the Polder/Adeos Bi-Directional Reflectance Product. International Journal of Remote Sensing, 25, 603-626. https://doi.org/10.1080/0143116031000116976

[42] Laurent, B., Marticorena, B., Bergametti, G., Chazette, P., Maignan, F. and Schmechtig, C. (2005) Simulation of the Mineral Dust Emission Frequencies from Desert Areas of China and Mongolia Using an Aerodynamic Roughness Length Map Derived from the Polder/Adeos 1 Surface Products. Journal of Geophysical Research, 110, D18S04. https://doi.org/10.1029/2004JD005013

[43] Callot, Y.B., Marticorena, B. and Bergametti, G. (2000) Geomorphologic Approach for Modeling the Surface Features of Arid Environments in a Model of Dust Emission: Application to the Sahara Desert. Geodinamica Acta, 13, 245-270.

https://doi.org/10.1080/09853111.2000.11105373

[44] Mallet, V., Quelo, D., Sportisse, B., Ahmed de Biasi, M., Debry, E., Korsakissok, I., Wu, L., Roustan, Y., Sartelet, K., Tombette, M. and Foudhil, H. (2007) Technical Note: The Air Quality Modeling System Polyphemus. Atmospheric Chemistry and Physic, 7, 5479-5487.

[45] Debry, E., Fahey, K., Sartelet, K., Sportisse, B. and Tombette, M. (2007) Technical Note: A New Size Resolved Aerosol Model (SIREAM). Atmospheric Chemistry and Physics, 7, 1537-1547. http://www.atmos-chem-phys.net/7/1537/2007/

[46] Couvidat, F., Debry, E., Sartelet, K. and Seigneur, C. (2012) A Hydrophilic/Hydrophobic Organic $\left(\mathrm{H}^{2} \mathrm{O}\right)$ Aerosol Model: Development, Evaluation and Sensitivity Analysis. Journal of Geophysical Research, 117, D10304.

[47] Nenes, A., Pandis, S.N. and Pilinis, C. (1998) Isorropia: A New Thermodynamic Equilibrium Model for Multiphase Multicomponent Inorganic Aerosols. Aquatic Geochemistry, 4, 123-152. https://doi.org/10.1023/A:1009604003981

[48] Yarwood, G., Rao, S., Yocke, M. and Whitten, G. (2005) Updates to the Carbon Bond Chemical Mechanism: CB05. Technical Report, Final Report to US EPA, RT-0400675.

[49] Kim, Y., Sartelet, K. and Seigneur, C. (2009) Comparison of Two Gas-Phase Chemical Kinetic Mechanisms of Ozone Formation over Europe. Journal of Atmospheric Chemistry, 62, 89-119. https://doi.org/10.1007/s10874-009-9142-5

[50] Kim, Y., Couvidat, F., Sartelet, K. and Seigneur, C. (2011) Comparison of Different Gas-Phase Mechanisms and Aerosol Modules for Simulating Particulate Matter Formation. Journal of the Air \& Waste Management Association, 61, 1218-1226.

[51] Zhang, L., Brook, J. and Vet, R. (2003) A Revised Parameterization for Gaseous Dry Deposition in Air Quality Models. Atmospheric Chemistry and Physics, 3, 2067-2082.

[52] Simpson, D., Fagerli, H., Jonson, J.E., Tsyro, S., Wind, P. and Tuovinen, J.P. (2003) Transboundary Acidification, Eutrophication and Ground Level Ozone in Europe. Part I: Unified EMEP Model Description. Technical Report 1, EMEP.

[53] Zhang, L., Gong, S., Padro, J. and Barrie, L. (2001) A Size-Segregated Particle Dry Deposition Scheme for an Atmospheric Aerosol Module. Atmospheric Environment, 35, 549-560. https://doi.org/10.1016/S1352-2310(00)00326-5

[54] Bond, T.C., Streets, D.G., Yarber, K.F., Nelson, S.M., Woo, J. and Klimont, Z. (2004) A Technology Based Global Inventory of Black and Organic Carbon Emissions from Combustion. Journal of Geophysical Research, 109, D14203. 
https://doi.org/10.1029/2003JD003697

[55] Monahan, E., Spiel, D. and Davidson, K. (1986) A Model of Marine Aerosol Generation via Whitecaps and Wave Disruption. In: Reidel, D., Ed., Oceanic Whitecaps and Their Role in Air-Sea Exchange Processes, Springer, Berlin, 167-174.

[56] Nana, B., Sanogo, O., Savadogo, P.W., Daho, T., Bouda, M. and Koulidiati, J. (2012) Air Quality Study in Urban Centers: Case Study of Ouagadougou, Burkina Faso. FUTY Journal of the Environment, 7.

[57] Boylan, J.W. and Russel, A.G. (2006) PM and Light Extinction Model Performance Metrics, Goals, and Criteria for Three-Dimensional Air Quality Models. Atmospheric Environment, 40, 4946-4959. https://doi.org/10.1016/j.atmosenv.2005.09.087

[58] Marticorena, B. and Bergametti, G. (1996) Two-Years Simulations of Seasonal and Interannual Changes of the Saharan Dust Emissions. Geophysical Research Letters, 23, 1921-1924.

[59] Song, H., Wang, K., Zhang, Y., Hong, C. and Zhou, S. (2017) Simulation and Evaluation of Dust Emissions with WRF-Chem (v3.7.1) and Its Relationship to the Changing Climate over East Asia from 1980 to 2015. Atmospheric Environment, 167, 511-522. https://doi.org/10.1016/j.atmosenv.2017.08.051

[60] Schütz, L., Jaenicke, R. and Pietrek, H. (1981) Saharan Dust Transport over the North Atlantic Ocean: Model Calculations and Measurements. In: Péwé, T.L., Ed., Desert Dust, Geological Society of America, 87-100. https://doi.org/10.1130/SPE186-p87

[61] Prospero, J.M. (1996) The Atmospheric Transport of Particles to the Ocean. In: Ittekkot, V., Schaefer, P., Honjo, S. and Depetris, P.J., Eds., Particle Flux in the Ocean, John Wiley and Sons, Hoboken, 19-52.

[62] Swap, R., Ulanski, S., Cobbett, M. and Garstang, M. (1996) Temporal and Spatial Characteristics of Saharan Dust Outbreaks. Journal of Geophysical Research, 101, 4205-4220.

[63] Ozer, P. (2001) Les lithometeores en region sahelienne. International Journal of Tropical Ecology and Geography, 24, 1-317.

[64] Kaufman, Y.J., Koren, I., Remer, L.A., Tanre, D., Ginoux, P. and Fan, S. (2005) Dust Transport and Deposition Observed from the Terra-Moderate Resolution Imaging Spectroradiometer (MODIS) Space-Craft over the Atlantic Ocean. Journal of Geophysical Research, 110, 4205-4220.

[65] Menut, L., Chiapello, I. and Moulin, C. (2009) Predictability of Mineral Dust Concentrations: The African Monsoon Multidisciplinary Analysis First Short Observation Period Forecasted with CHIMERE-DUST. Journal of Geophysical Research, 114. 